\title{
Fault models of unusual tsunami in the 17th century along the Kuril trench
}

\author{
K. Satake ${ }^{1 *}$, F. Nanayama ${ }^{2}$, and S. Yamaki ${ }^{3}$ \\ ${ }^{1}$ Active Fault Research Center, AIST, Tsukuba 305-8567, Japan \\ ${ }^{2}$ Institute of Geology and Geoinformation, AIST, Tsukuba 305-8567, Japan \\ ${ }^{3}$ Seamus Co., Ltd., Niigata 950-3304, Japan
}

(Received January 20, 2008; Revised July 4, 2008; Accepted July 31, 2008; Online published October 15, 2008)

\begin{abstract}
Geologic evidence has shown that unusual tsunami deposits are traced as high as $18 \mathrm{~m}$ above the current sea level or as far as 1-4 km inland from the shoreline on the Pacific coast of eastern Hokkaido, and that such unusual tsunamis have recurred at about 500 year interval with the most recent event in the 17th century. We computed coastal tsunami heights along the Hokkaido and Sanriku coasts and inundation at five coastal marshes in Hokkaido where the tsunami deposits were mapped. Three types of faults were tested: giant fault, tsunami earthquake and interplate earthquake models. The giant fault model, with the largest seismic moment, yields the lowest tsunami heights and smaller inundation than the distribution of tsunami deposits in Hokkaido, while the tsunami heights are largest in Sanriku. The tsunami earthquake model yields little inundation in Hokkaido and the smallest heights in Sanriku. The interplate earthquake model produces the largest tsunami heights and inundation in Hokkaido, reproducing the distribution of tsunami deposits on the Nemuro coast. The multi-segment interplate earthquake with variable slip (10 $\mathrm{m}$ on Tokachi and $5 \mathrm{~m}$ on Nemuro segment) can reproduce the distribution of tsunami deposits on the Tokachi coast as well, and considered as the best source model for the 17th century tsunami, although the Sanriku tsunami heights are more than $3 \mathrm{~m}$, exceeding an inferred detection threshold of historical documents. The seismic moment is estimated as $8 \times 10^{21} \mathrm{~N} \mathrm{~m}\left(M_{\mathrm{w}} 8.5\right)$. Comparison with the recent 2003 Tokachi-oki earthquake indicates that the 17th century tsunami source was longer and located further offshore at shallower depth.
\end{abstract}

Key words: Tsunami, tsunami deposit, numerical simulation, paleoseismology, Kuril trench, multi-segment earthquake.

\section{Introduction}

Great $(M>8)$ earthquakes have recurred along the southern Kuril trench, where the Pacific plate subducts beneath northern Japan at a rate of about $8 \mathrm{~cm} / \mathrm{yr}$ (Earthquake Research Committee, 2004). In the Tokachi-oki (offshore Tokachi) region of Hokkaido, the most recent earthquake occurred on September 26, 2003 ( $M_{\mathrm{JMA}}$ 8.0), which was preceded by the March 4, 1952 ( $\left.M_{\text {JMA }} 8.2\right)$ Tokachioki earthquake (Fig. 1). Seismogram analysis and aftershock distributions (Yamanaka and Kikuchi, 2003; Hamada and Suzuki, 2004) indicate that the source regions of these Tokachi-oki earthquakes were similar, while the tsunami data (coastal heights and waveforms on tide gauges) show that the 1952 tsunami source extended to the east (Hirata $e t$ al., 2003, 2004; Tanioka et al., 2004a; Satake et al., 2006). The difference in tsunami source areas may be related to the fore arc subsurface structure (Okamura et al., 2008). Historical documents indicate that similar Tokachi-oki earthquake also occurred on April 25, 1843, with an estimated size of

*Present address: Earthquake Research Institute, University of Tokyo, Tokyo 113-0032, Japan.

Copyright (c) The Society of Geomagnetism and Earth, Planetary and Space Sciences (SGEPSS); The Seismological Society of Japan; The Volcanological Society of Japan; The Geodetic Society of Japan; The Japanese Society for Planetary Sciences; TERRAPUB.
M 8.0 (Hatori, 1984; Utsu, 1999). To the east in Nemurooki (offshore Nemuro) region, the most recent earthquake occurred on June 17, 1973 ( $M_{\mathrm{JMA}}$ 7.4) (Shimazaki, 1974; Aida, 1978). The penultimate event on March 22, 1894 (M 7.9; Utsu, 1999) seemed to have ruptured the larger area (Hatori, 1974; Tanioka et al., 2007).

Paleoseismological studies have shown evidence of unusual tsunamis and coastal movements in eastern Hokkaido. Prehistoric tsunami deposits underlie coastal marshes and lagoons (Nanayama et al., 2003) or coastal cliffs (Hirakawa et al., 2005) along $200 \mathrm{~km}$ of eastern Hokkaido's Pacific coast. Such unusual tsunami deposits, found much further inland than those from the historical earthquakes along the Kuril trench or across the Pacific ocean, have been attributed to unusual earthquakes along the Kuril trench with an average recurrence interval of about 500 years, and the most recent tsunami was dated in the 17th century (Nanayama et al., 2003). Coastal geology also indicates that the eastern coast of Hokkaido has uplifted by about $1 \mathrm{~m}$ in the 17th century (Atwater et al., 2004). Such uplift, also repeated at about 500 year interval (Kelsey et al., 2006), has been interpreted due to postseismic slip on the deeper part of interplate earthquakes (Sawai et al., 2004).

In this paper, we make tsunami numerical computations to estimate the 17th century coastal heights and inundation from several kinds of fault models. The estimated tsunami 

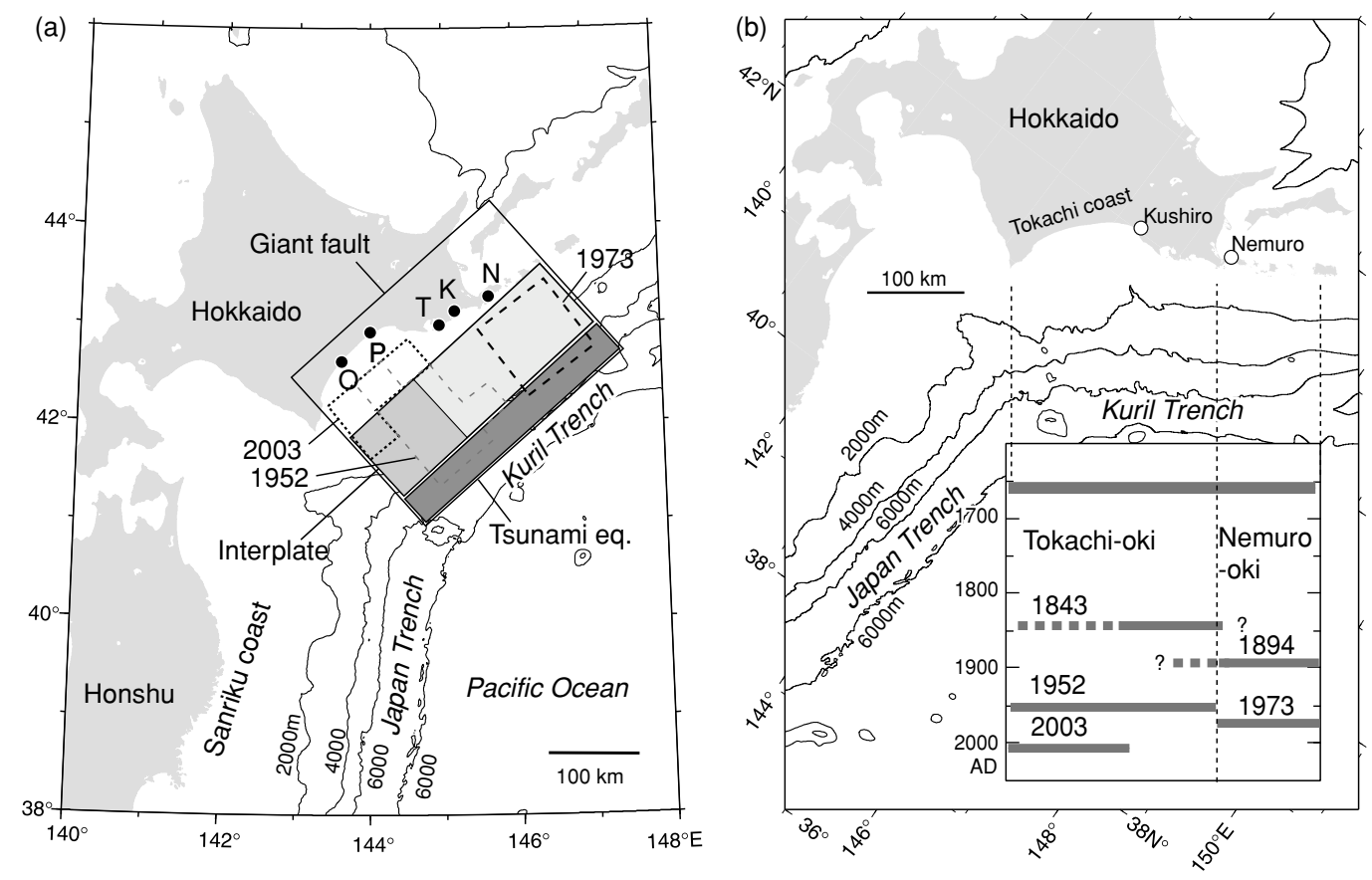

Fig. 1. Location maps. (a) Three types of fault models (giant fault, interplate earthquake and tsunami earthquake models), as well as those of the 1952 and 2003 Tokachi-oki earthquake (Satake et al., 2006; Tanioka et al., 2004a) and 1973 Nemuro-oki earthquakes (Aida, 1978) are shown. Five marshes where tsunami deposits were mapped are shown by black circles with location codes (N: Nambu, K: Kiritappu, T: Tokotan, P: Pashukuru, O: Oikamanai). (b) Space-time diagram of the great earthquakes along the southern Kuril trench, off Nemuro and Tokachi coasts (Satake et al., 2005).

heights and inundation areas are compared with the paleoseismological data on the Hokkaido coast, as well as historical tsunami heights along the Sanriku coast in northern Honshu. As fault models, we compare a giant fault, a tsunami earthquake, and an interplate earthquake. We will show that a multi-segment interplate earthquake with large and non-uniform slip can best explain the paleotsunami evidence.

\section{Summary of Paleoseismological and Historical Data}

\subsection{Tsunami deposits}

Unusual tsunami deposits have been found in coastal marshes and lagoons along the Pacific coast of Hokkaido (Sawai, 2002; Nanayama et al., 2003, 2007). Here we briefly summarize the distribution of tsunami deposits in five coastal marshes mapped and compiled in Geological Survey of Japan (2004). The five marshes are, from east to west, Nambu pond in Nemuro city, Kiritappu marsh in Hamanaka town, Tokotan pond in Akkeshi town, Pashukuru pond in Shiranuka town and Onbetsu (Kushiro city), and Oikamanai pond in Taiki town.

Volcanic ash layers were used to correlate and date the tsunami deposits (Nanayama et al., 2003). The youngest and most prominent ash layers are from multiple eruptions in the 17-18th centuries from volcanoes in southern Hokkaido: Tarumai volcano in AD 1739 (Ta-a), in AD1667 (Ta-b), Komagatake volcano in AD 1694 (Ko-c2), and Usu volcano in 1663 (Us-b). Two eruptions around the 10th century, Mashu in eastern Hokkaido (Ma-b) and Baitou-shan in Korea-China border (B-Tm), were also used. For older tsunami deposits, ash layers from Tarumai around $2.5 \mathrm{ka}$ (Ta-c2) and Komagatake at around $7 \mathrm{ka}$ (Ko-g) were used.
One or two layers of tsunami deposits, found above the 17th century volcanic ash layers and named Ts 1 and Ts2, are correlated with historical tsunamis such as those from the 1843 Tokachi-oki earthquake or the 1960 Chilean earthquake. Their distribution is usually limited along the coasts, but extended about $500 \mathrm{~m}$ around Tokotan pond and about $1 \mathrm{~km}$ around Nambu pond.

Two layers of tsunami deposits are found between the volcanic ash layers of the 17th century (mostly Ta-b) and the 10 th century (B-Tm with Ma-b). Named Ts3 and Ts4, they were dated as in the 17th century and around the 13-14th century, respectively (Nanayama et al., 2007). Their distributions were mapped in the five marshes (Figs. 2 and 3).

Around Nambu pond, both Ts 3 and Ts4 are traced more than $2 \mathrm{~km}$ from the coast along profile $\mathrm{N}-\mathrm{N}^{\prime}$ (Fig. 2(b)). In Kiritappu marsh (Fig. 3), both Ts3 and Ts4 (called KS3 and KS4 in Nanayama et al., 2007) are traced for about $3 \mathrm{~km}$ along two profiles, lines $\mathrm{MG}$ and $\mathrm{BW}$, toward the end of the marsh. In addition, they are found at the northern and southern edges of the marsh (Fig. 3). Near the landward limits, only Ts4 (KS4) deposits are found, indicating that the inundation of the Ts4 tsunami was larger than that of Ts3 (KS3).

At the three other (southwestern) marshes, Ts3 deposits are traced for longer distances than Ts4 deposits (Fig. 2). Around Tokotan pond, both Ts 3 and Ts 4 deposits are traced about $1.5 \mathrm{~km}$ from the coast. Around Pashukuru pond, Ts 4 deposits are limited near the coast but Ts 3 are traced for nearly $4 \mathrm{~km}$ from the coast. Similarly, around Oikamanai pond, Ts 3 deposits are traced for about 3 and more than $4 \mathrm{~km}$ along two profiles, while Ts 4 deposits are found only around the coast.

The distribution of tsunami deposits indicate minimum 

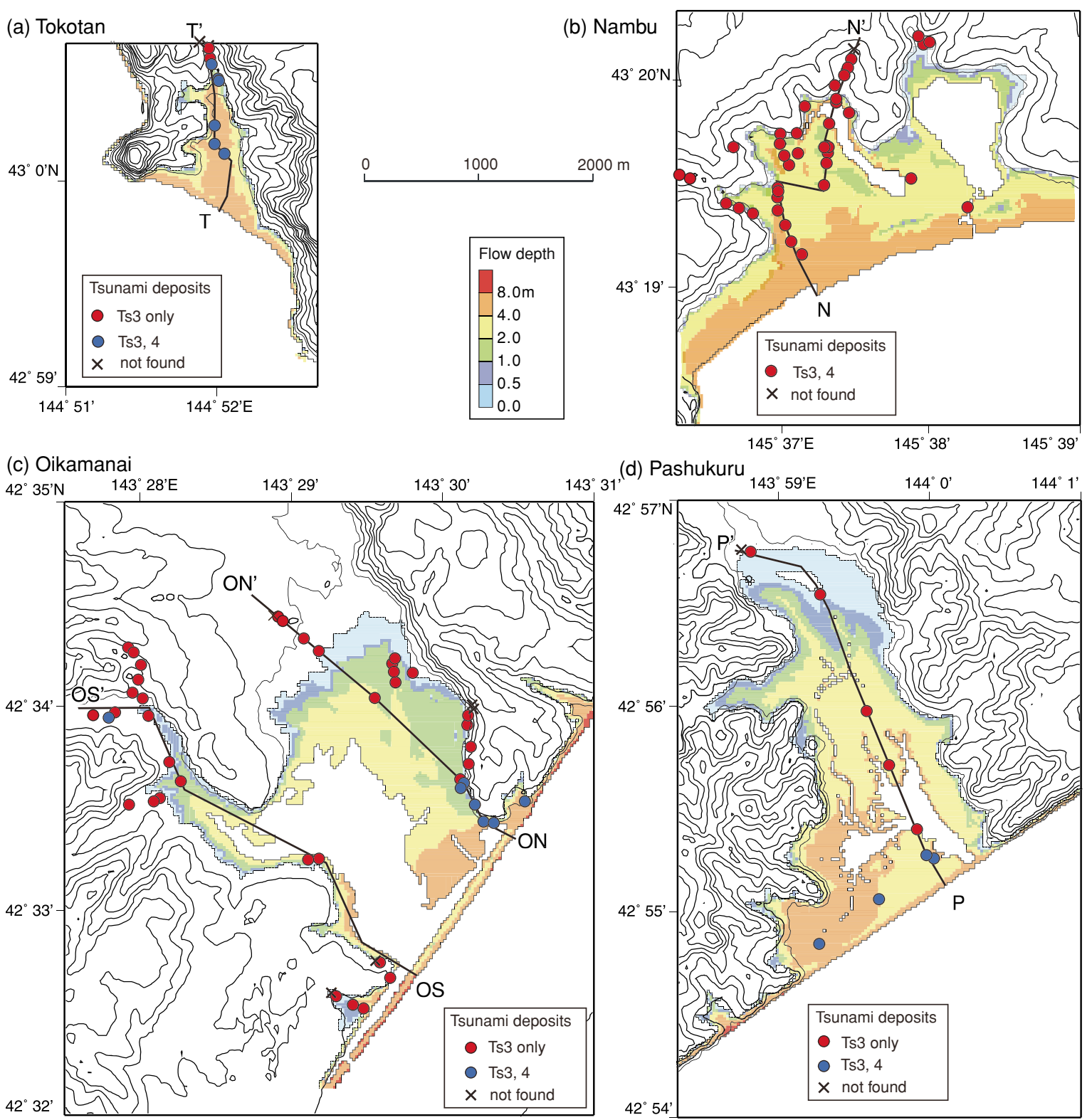

(d) Pashukuru $143^{\circ} 59^{\prime} \mathrm{E} \quad 144^{\circ} 0^{\prime} \quad 144^{\circ} 1^{\prime}$

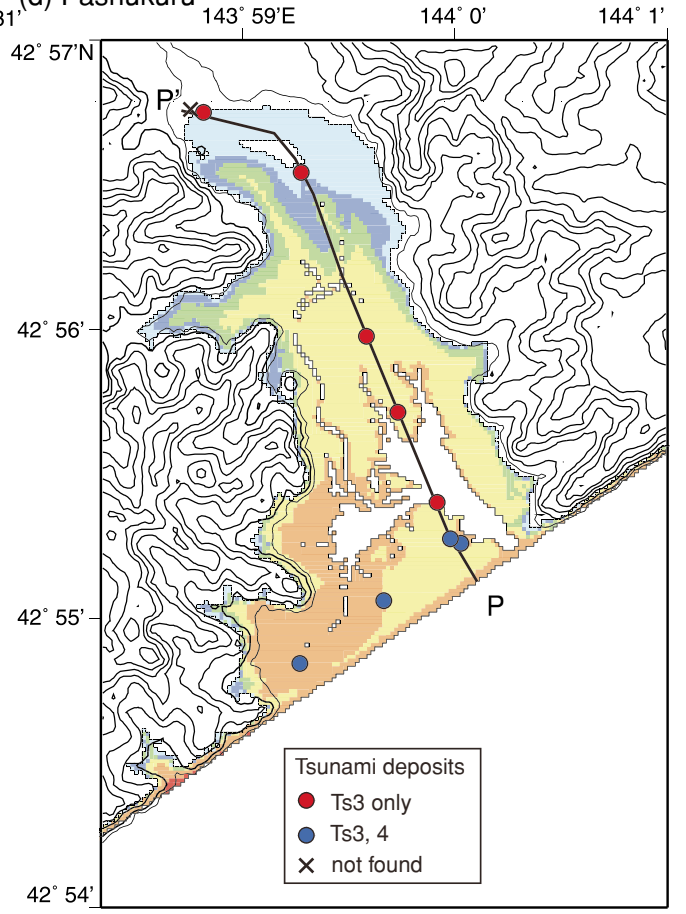

Fig. 2. Maps for the four marshes: (a) Tokotan, (b) Nambu, (c) Oikamanai and (d) Pashukuru. Location of tsunami deposits and computed inundation areas from T10N5 model are shown. Ts 3 and Ts4 deposits are for those in the 17th and around 13-14th century, respectively. The contour interval for topography is $10 \mathrm{~m}$.

inundation area; as the tsunami slows down and the flow depth becomes small near the inundation limit, it may not be able to transport sand deposits. The difference in spatial distribution of Ts3 and Ts4 deposits indicate that the sources of tsunamis that brought Ts 3 and Ts 4 deposits are different. In this paper, we concentrate the source model of the 17 th century earthquake that is responsible for Ts 3 deposits, although we will briefly discuss the source model for Ts4 later (in Section 6.2).

\subsection{Coastal tsunami heights}

The coastal tsunami heights from the 17th century tsunami, that brought Ts3 deposits, have been inferred on the Tokachi coast. Hirakawa et al. (2005) studied the tsunami deposits on coastal cliffs of marine terraces. The altitude of tsunami deposits on marine terraces is at maximum $18 \mathrm{~m}$ near Oikanamai pond, and mostly more than $10 \mathrm{~m}$ along the Tokachi coast (Fig. 4). Because they are on the coastal cliffs, their altitude may indicate the minimum coastal tsunami height of the 17 th century tsunami, neglecting the possible crustal deformation or coastal erosion in the last few centuries.

\subsection{Historical documents on Sanriku coast}

The oldest great earthquake documented along the southern Kuril trench is the 1843 earthquake, because the written history in eastern Hokkaido started around AD 1800. However, in northern Honshu, earthquakes and tsunamis have been documented as far back as around AD 1600 (Satake, 2004). In the 17 th century, damage from two tsunamis in 1611 and 1677 were recorded (Hatori, 1975; Fig. 4), while Imamura (1934) listed three more tsunamis with relatively smaller size. The 1611 Sanriku tsunami was in similar size or larger than the 1896 Sanriku tsunami, the worst tsunami disaster in Japan caused by a "tsunami earthquake." The 1611 tsunami heights were estimated as 3 to $20 \mathrm{~m}$. The 

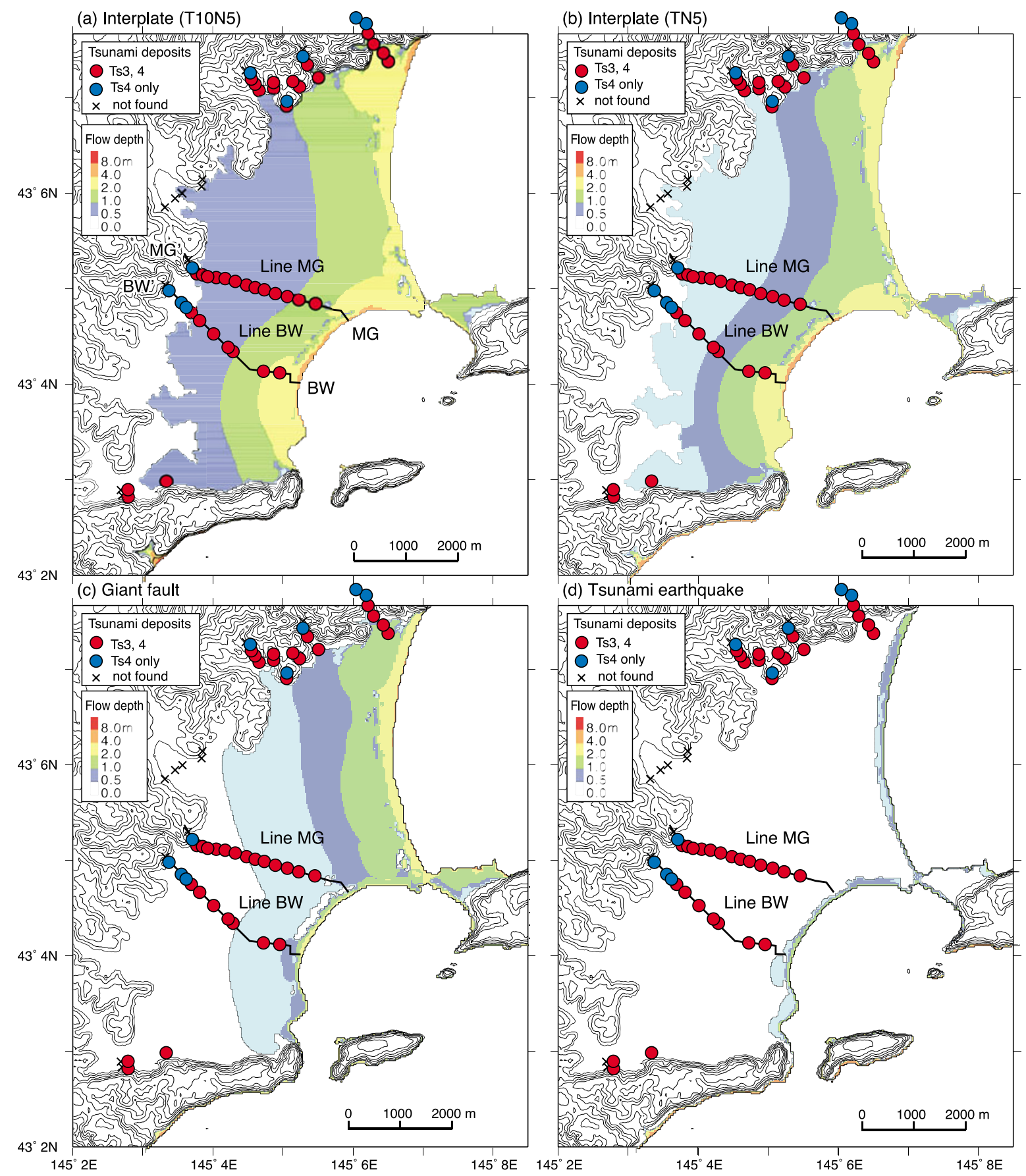

Fig. 3. Distribution of tsunami deposits and computed tsunami inundation area in Kiritappu marsh from (a) interplate earthquake (the T10N5 model), (b) interplate earthquake (the TN5 model), (c) giant fault model, and (d) tsunami earthquake model. The contour interval for topography is 10 m.

1677 tsunami, post-dated of some of the 17 th century volcanic ash in Hokkaido (Us-b and Ta-b), was similar to that from the 1968 Tokachi-oki earthquake (despite its name, located off northeast coast of Sanriku), and the tsunami heights were between 2 and $6 \mathrm{~m}$. From these tsunami heights in the 17 th century, it is suggested that a tsunami that produces coastal tsunami heights more than $3 \mathrm{~m}$ would have caused damage and likely to be documented. In other words, in order to escape from historical documents in Tohoku, the tsunami heights along the Sanriku coast must be $3 \mathrm{~m}$ or less. This gives an important constraint for modeling the tsunami source along the Kuril trench.

\section{Fault Models}

Paleoseismological evidence indicates that the 17th century tsunami source was much larger than that of the typical interplate earthquakes, such as the 1952 and 2003 Tokachi-oki earthquakes, and extended along the Nemuro and Tokachi coasts. As candidates of the fault model that produced the 17 th century tsunami, we consider three types of fault models on the plate interface (Table 1). They are (1) a giant fault model, (2) a tsunami earthquake model and (3) an interplate earthquake model. For these three models, the fault length is fixed at $300 \mathrm{~km}$, covering the Tokachi and Nemuro segments, the strike is fixed at $228^{\circ}$ (parallel to the Kuril trench), the dip angle is $20^{\circ}$ (the average dip 
Table 1. Fault models and their parameters.

\begin{tabular}{|c|c|c|c|c|c|c|c|c|c|c|c|}
\hline Model & $\begin{array}{c}\text { Length } \\
\mathrm{km}\end{array}$ & $\begin{array}{c}\text { Width } \\
\text { km }\end{array}$ & $\begin{array}{c}\text { Slip } \\
\text { m }\end{array}$ & $\begin{array}{c}\text { Strike } \\
\text { deg }\end{array}$ & $\begin{array}{l}\text { Dip } \\
\text { deg }\end{array}$ & $\begin{array}{c}\text { Rake } \\
\text { deg }\end{array}$ & $\begin{array}{l}\text { Depth } \\
\text { km }\end{array}$ & $\begin{array}{c}\text { Latitude } \\
\operatorname{deg} \mathrm{N}\end{array}$ & $\begin{array}{c}\text { Longitude } \\
\operatorname{deg} \mathrm{E}\end{array}$ & $\begin{array}{c}M_{\mathrm{o}} \\
10^{21} \mathrm{~N} \mathrm{~m}\end{array}$ & $M_{\mathrm{w}}$ \\
\hline Giant fault & 300 & 250 & 5 & 228 & 20 & 90 & 0 & 42.6741 & 147.6091 & 15 & 8.7 \\
\hline Interplate (TN5) & 300 & 100 & 5 & 228 & 20 & 90 & 17 & 42.9881 & 147.2244 & 6 & 8.5 \\
\hline Interplate (T10N5) & 200 & 100 & 5 & 228 & 20 & 90 & 17 & 42.9881 & 147.2244 & 8 & 8.5 \\
\hline 2003 T-OS & 100 & 100 & 5 & 228 & 20 & 90 & 17 & 41.8203 & 145.3784 & 2 & 8.1 \\
\hline
\end{tabular}

Depth, longitude and latitude are for the easternmost corner of each fault. For the computation of $M_{\mathrm{o}}\left(\right.$ seismic moment), the rigidity of $4 \times 10^{10} \mathrm{~N} / \mathrm{m}^{2}$ is assumed.
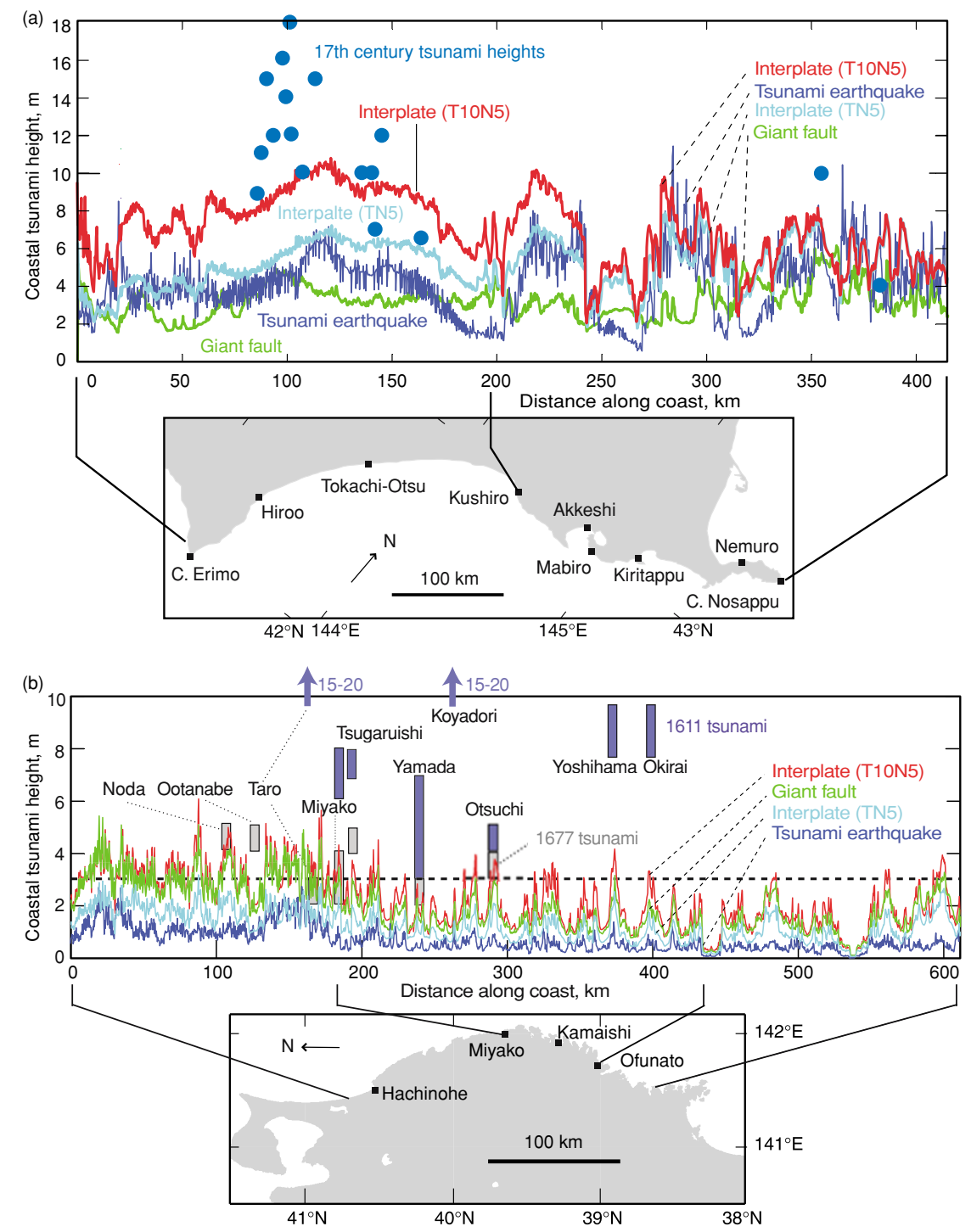

Fig. 4. Coastal tsunami heights computed from the four different models for (a) Hokkaido and (b) Sanriku coasts. In (a), inferred heights for the 17th century tsunami deposits (Hirakawa et al., 2005) are shown by blue circles. In (b), tsunami height ranges of the 1611 and 1677 tsunamis estimated from historical documents (Hatori, 1975) are shown by vertical bars. The detection threshold in historical documents, estimated as $3 \mathrm{~m}$ on the Sanriku coast, is also shown.

angle of subducting Pacific plate), and the slip (rake) angle is $90^{\circ}$ (pure dip-slip motion on a reverse fault). We first fix a slip amount to $5 \mathrm{~m}$ for three kinds of fault models to examine the effects of the other parameters. This slip amount is larger than the average slip but closer to the maximum slip of the 1952 and 2003 Tokachi-oki earthquakes (Satake et al., 2006; Tanioka et al., 2004a) or the 1973 Nemuro-oki earthquake (Tanioka et al., 2007).

The crustal deformation due to faulting is computed by using the equations of Mansinha and Smylie (1971). The map and cross-sectional views of vertical component of crustal deformation are shown in Fig. 5. 


\subsection{Giant fault model}

The first model is a giant fault; the fault width is $250 \mathrm{~km}$ extending from $0 \mathrm{~km}$ (seafloor) to $85 \mathrm{~km}$ depth. Because the fault plane extends to beneath the land area, the coast is expected to rise at the time of earthquake. Ikeda (1996) proposed that such a giant fault is needed to solve a paradox of crustal strain or movement in the geodetic and geologic time scales (see also Atwater et al., 2004). While the deepest end $(85 \mathrm{~km})$ may be below the brittle-ductile transition zone with temperature of about $450^{\circ} \mathrm{C}$ (Shimamoto et al., 1993), the plate coupling is inferred to be extended to this depth (Ito et al., 2000; Suwa et al., 2006). Sawai et al. (2004), on the basis of diatom analysis, proposed that the deep slip occurred within decades after the 17th century earthquake. Because the giant fault is widest, the wavelength of crustal deformation is largest (Fig. 5(e)).

\subsection{Tsunami earthquake model}

A "tsunami earthquake" is such an earthquake that produces much larger tsunami than expected from seismic waves (Kanamori, 1972). The fault model of the 1896 Sanriku earthquake, typical tsunami earthquake along the Japan trench, was proposed as a large $(5.7 \mathrm{~m})$ slip on a narrow (50 km wide) fault near the trench axis (top depth $0 \mathrm{~km}$ ) (Tanioka and Satake, 1996). Here we consider a similar fault, $50 \mathrm{~km}$ wide extending from seafloor $(0 \mathrm{~km})$ to $17 \mathrm{~km}$ depth. The narrowest fault among the three types yields the seafloor deformation with the shortest wavelength.

\subsection{Interplate earthquake model}

For the interplate earthquake model, the fault width is set as $100 \mathrm{~km}$, the depth ranging from 17 to $51 \mathrm{~km}$. This depth range corresponds to ordinary seismogenic zone of subduction zones (Tichelaar and Ruff, 1993; Hyndman et al., 1997).

For slip amount, we first consider a uniform slip of $5 \mathrm{~m}$ over the Tokachi and Nemuro segments (TN5). As we will discuss later, a heterogeneous fault model $(10 \mathrm{~m}$ on the Tokachi segment and $5 \mathrm{~m}$ on the Nemuro segment, called T10N5) is also considered.

The interplate earthquake fault models produce seafloor uplift above the fault. Because the down-dip end of the fault is also located offshore, both coast and nearshore seafloor are expected to subside (Figs. 5(a), (e)).

\section{Numerical Computations of Tsunami Inunda- tion}

\subsection{Method}

The propagation and inundation of tsunami are computed by using finite-difference method on actual bathymetry and topography. The equation of motion is

$$
\begin{aligned}
\frac{\partial M}{\partial t} & +\frac{\partial}{\partial x}\left(\frac{M^{2}}{D}\right)+\frac{\partial}{\partial y}\left(\frac{M N}{D}\right)+g D \frac{\partial \eta}{\partial x} \\
& +\frac{g n^{2}}{D^{7 / 3}} M \sqrt{M^{2}+N^{2}}=0 \\
\frac{\partial N}{\partial t}+ & \frac{\partial}{\partial x}\left(\frac{M N}{D}\right)+\frac{\partial}{\partial y}\left(\frac{N^{2}}{D}\right)+g D \frac{\partial \eta}{\partial y} \\
& +\frac{g n^{2}}{D^{7 / 3}} N \sqrt{M^{2}+N^{2}}=0
\end{aligned}
$$

and the equation of continuity is

$$
\frac{\partial \eta}{\partial t}+\frac{\partial M}{\partial x}+\frac{\partial N}{\partial y}=0
$$

where $x$ and $y$ are horizontal Cartesian coordinates, $\eta$ is water height, $D$ is total depth (= still water depth $+\eta), M$ and $N$ are flux (flow rate, or velocity times total depth) in $x$ and $y$ directions, and $n$ is the Manning roughness constant $\left(0.03 \mathrm{~m}^{-1 / 3} \mathrm{~s}\right)$ (IUGG/IOC Time Project, 1997). In the deep ocean outside the source area, the nonlinear advection (2nd and 3rd) terms and the bottom friction (5th) term in Eq. (1) are neglected.

The seafloor deformation computed in the previous section is used as the initial condition, which is provided over a duration of $1 \mathrm{~min}(60 \mathrm{~s})$. For the giant fault case, the coast is uplifted at the time of earthquake. We assume that the current topography is post-seismic land level, hence we subtracted the amount of coseismic deformation from the current topography before the computation, and include the coseismic change in the computation.

The computational area is approximately from $140^{\circ} \mathrm{E}$ to $150^{\circ} \mathrm{E}$ and $36^{\circ} \mathrm{N}$ to $46^{\circ} \mathrm{N}$. In the deep ocean including the source area, the grid size is basically $675 \mathrm{~m}(2,025 \mathrm{~m}$ is used on the peripheral areas), and finer grids with $225 \mathrm{~m}$ interval is used on the coasts. Very fine grids with $75 \mathrm{~m}$ and $25 \mathrm{~m}$ intervals are used at the marshes for the computation of inundation.

The boundary conditions are classified into the following three. On the boundary to outer sea, radiation condition based on the method of characteristics in which the tsunami waves goes out with long-wave speed (IUGG/IOC Time Project, 1997) is assumed. On the five marshes where the tsunami inundation is computed, the boundary moves depending on the topographic height and water height (Iwasaki and Mano, 1979), and the flux is calculated when the total depth $D>10^{-5} \mathrm{~m}$. On the other coasts, total reflection is assumed.

The computation time step is set as $0.5 \mathrm{~s}$ to satisfy the stability condition of finite-difference method. The computation is made for 3 hours after the earthquake occurrence.

\subsection{Bathymetry and topography data}

The bathymetry data around Japan is provided as digital contour maps by MIRC (Marine Information Research Center, Japan Hydrographic Association). To the east of $148^{\circ}$ E, ETOPO2 data based on Smith and Sandwell (1997) are used.

For coastal areas, we collected detailed bathymetry maps surveyed by fisherman's associations with scale of either $1 / 25,000$ or $1 / 20,000$, digitized them and made grids.

As land topographic data, we used digital elevation model (50 m grid) provided by Geographical Survey Institute, supplemented with high resolution maps made by local governments or our own survey data.

We assumed that the 17th century topography of marshes is the same as today, except for the giant fault model where we considered the coseismic crustal deformation. During the interseismic period in the last century, the Pacific coast of Hokkaido has subsided nearly a meter (see Atwater et al., 2004), but we do not have information about co- or post-seismic uplift of the 17 th century earthquake (Sawai 

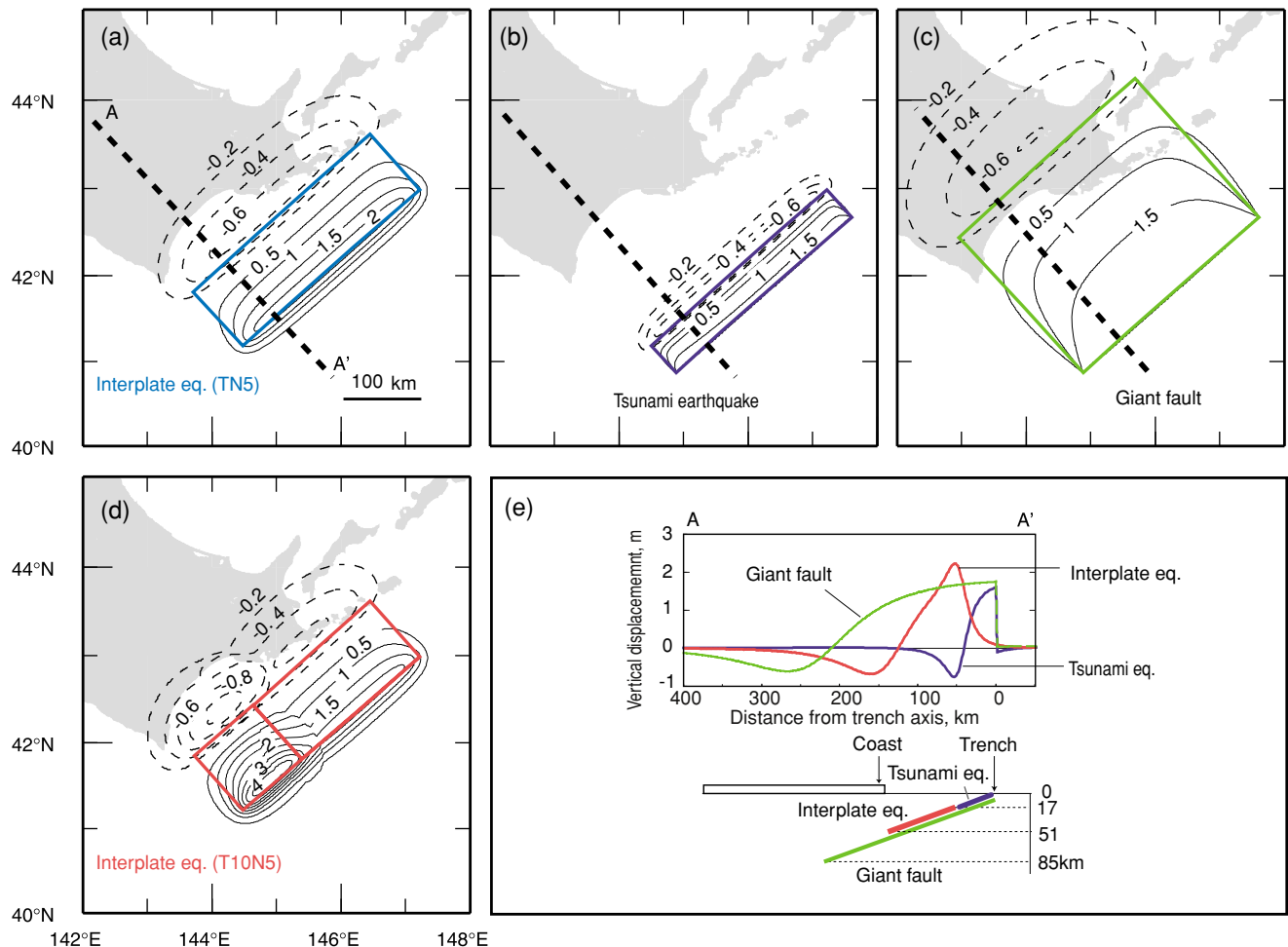

$(\mathrm{e})$
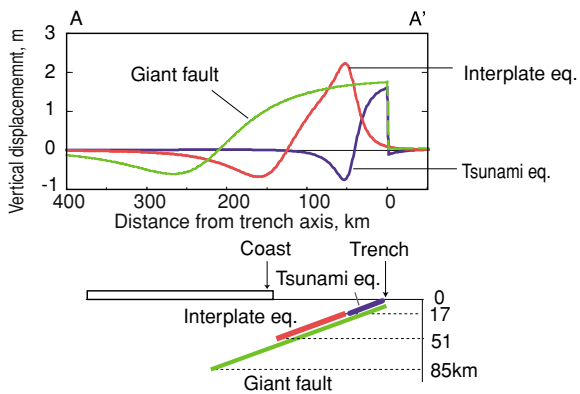

Fig. 5. Four fault models used for computations of coastal tsunami heights and inundation in five marshes. (a) Interplate earthquake (TN5) is $300 \mathrm{~km}$ long and $100 \mathrm{~km}$ wide with a uniform slip of $5 \mathrm{~m}$. (b) Tsunami earthquake model is $50 \mathrm{~km}$ wide near the trench axis. The slip is $5 \mathrm{~m}$. (c) Giant fault model is $250 \mathrm{~km}$ wide with a uniform slip of $5 \mathrm{~m}$. (d) Interplate model (T10N5) has the same fault size as (a) but the slip is $10 \mathrm{~m}$ on the Tokachi segment (100 km long) and $5 \mathrm{~m}$ in Nemuro segment (200 km long). See Table 1 for the other fault parameters. (e) Cross-section of seafloor and ground surface deformation along the dashed line in (a) through (c).
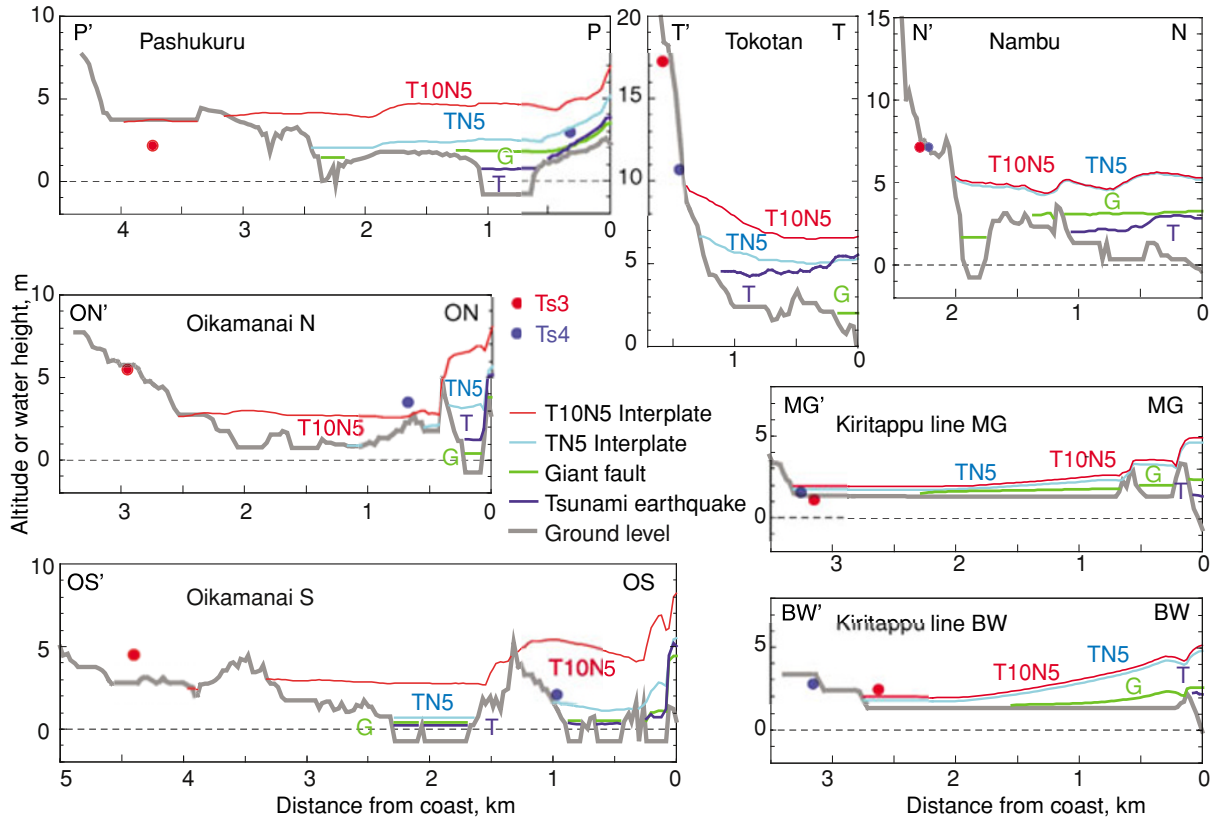

Fig. 6. Tsunami heights on profiles along seven lines in five marshes (solid lines in Figs. 2 and 3 ). The most inland location of the tsunami deposits (blue and red circles; see Figs. 2 and 3 ) and computed tsunami heights from the four fault models are shown.

et al., 2004) accurate enough to be used for reconstruction of topography.
5. Computation Results and Comparison 5.1 Coastal tsunami heights in Hokkaido and Sanriku The coastal tsunami heights calculated from different fault models are shown in Fig. 4. Along the Hokkaido coast, tsunami heights from the interplate earthquake model (TN5) range 2 to $8 \mathrm{~m}$. The tsunami heights from the tsunami 
earthquake model vary locally; they exceed $10 \mathrm{~m}$ at places but smaller than TN5 along the Tokachi coast. The tsunami heights from the giant fault are in general lowest, 2 to $6 \mathrm{~m}$. These three fault models have the same slip amount $(5 \mathrm{~m})$, hence the seismic moment is largest for the giant fault, but the tsunami heights are smallest. The giant fault produces the widest seafloor deformation (see Fig. 5(e)), which extends under coast and land, hence both seafloor and coast are uplifted. As a result, the tsunami heights on the uplifted coast may be relatively small. The shortest wavelength of seafloor deformation of the tsunami earthquake may be attributed to the local variability in coastal tsunami heights.

Because the tsunami heights from these three models are all smaller than the 17 th century tsunami heights, more than $10 \mathrm{~m}$ inferred by Hirakawa et al. (2005) along the Tokachi coast, we increase the slip amount to $10 \mathrm{~m}$ in the Tokachi-oki segment. This variable, yet still simple, slip model of interplate earthquake, T10N5, produces tsunami heights closer to the inferred tsunami heights. The maximum height, $18 \mathrm{~m}$, was not reproduced by numerical computation. It is possible that this maximum height is due to local topographic effects that cannot be reproduced in our numerical simulation (with the coastal grid size of $225 \mathrm{~m}$ ) or affected by the possible sea level change due to crustal deformation or by coastal erosion in the last few centuries (see Section 4.2).

Comparison of tsunami heights of T10N5 and TN5 shows that they are similar on the Nemuro coast but different on the Tokachi coast, indicating that the coastal tsunami heights are controlled by the slip on fault in front of the coast (in this case, the Tokachi segment), but rather insensitive to the slip on the neighboring (Nemuro) segment.

The tsunami heights along the Sanriku coast are proportional to the fault width or the seismic moment. For the three models with the same slip amount, the giant fault (250 km wide) produces the largest tsunami heights, followed by the interplate earthquake ( $100 \mathrm{~km}$ wide), then the tsunami earthquake $(50 \mathrm{~km}$ wide). The tsunami heights from the T10N5 model are similar to those of giant fault model, reaching more than $4 \mathrm{~m}$ on the northern Sanriku coast, and exceed $3 \mathrm{~m}$ at places on the southern coast.

The computed tsunami heights from the T10N5 and giant fault models are also similar to the inferred heights of the 1677 earthquake. As we discussed in Section 2.3, if the tsunami heights exceeded $3 \mathrm{~m}$ in the 17 th century, the tsunami would have caused damage and should have been documented. Lack of historical records implies that the 17 th century tsunami must be smaller than $3 \mathrm{~m}$ along the Sanriku coast.

\subsection{Tsunami inundation at Kiritappu marsh}

In the Kirittapu marsh, the interplate fault models (TN5 and T10N5) produce the largest inundation (Fig. 3). The inundation area and flow depth are similar for both models (Figs. 6 and 7), because the tsunamis reach the northern and western edges of the marsh. The inundation area from the giant fault model is smaller, without reaching the edge of the marsh or locations of tsunami deposits. The tsunami earthquake model yields little inundation to the marsh.

Tsunami flow depths above ground surface along the two profiles are computed (Fig. 6). Then the computed inun-
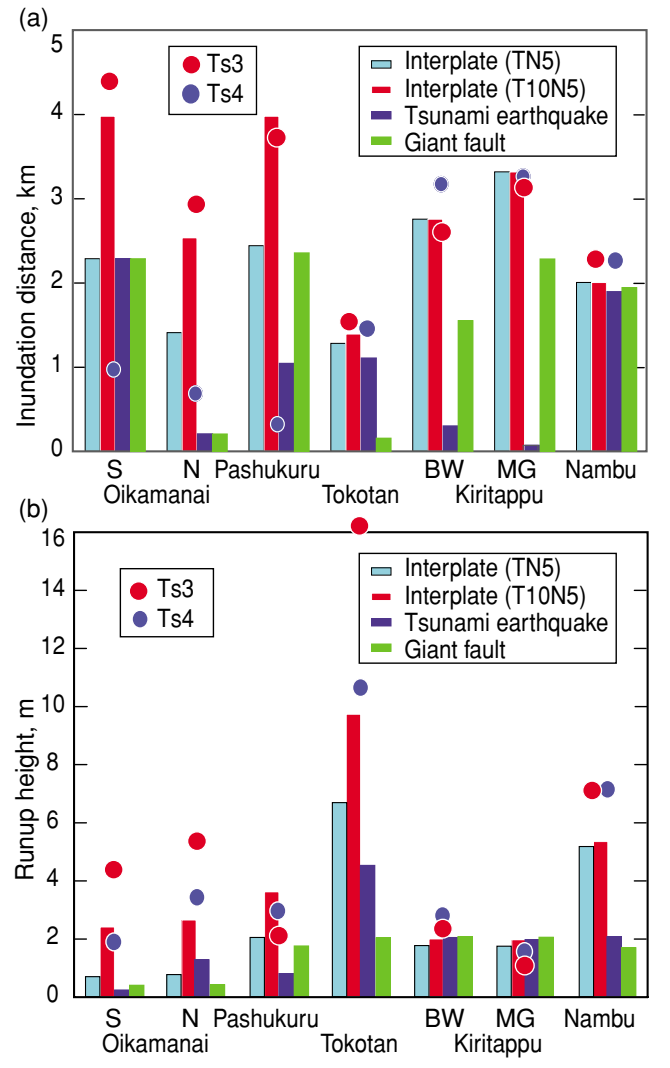

Fig. 7. Maximum inundation distances from coast line (a) and runup heights (b) for tsunami deposits (blue and red circles) and the computed tsunami inundation from the four different fault models along the seven profiles in five marshes.

dation distance and maximum runup heights along the profiles are compared with the locations of tsunami deposits (Fig. 7). Because the topography of Kiritappu marsh is flat, the runup heights are similar for different models, but the inundation distances are very different among the models (Fig. 6). The computed tsunami from the interplate fault models reaches about $3 \mathrm{~km}$, while that from the giant fault model reaches 2.3 and $1.5 \mathrm{~km}$ on the $\mathrm{MG}$ and $\mathrm{BW}$ lines. Only the interplate earthquake models (T10N5 and TN5) can reproduce the distribution of the 17 th century tsunami deposits in the Kiritappu marsh.

\subsection{Tsunami inundation at other marshes}

Similar comparisons are made for the other marshes. Around Nambu pond, the computed inundation distances along the profile are similar for the four models, but the runup heights at the inundation limits are different (Figs. 6 and 7). Again, interplate earthquake (T10N5 and TN5) models produce both inundation distances and runup heights closer to those of the tsunami deposits, while the runup heights from the giant fault and tsunami earthquake models are much lower than the altitudes of tsunami deposits.

Around Tokotan pond, computed inundation distances are similar for the interplate earthquakes (T10N5 and TN5) and the tsunami earthquake, but that from the giant fault model is much shorter. The runup height is highest for the T10N5 model, followed by TN5, then the tsunami earthquake model (Fig. 7). The 17th century tsunami deposit 


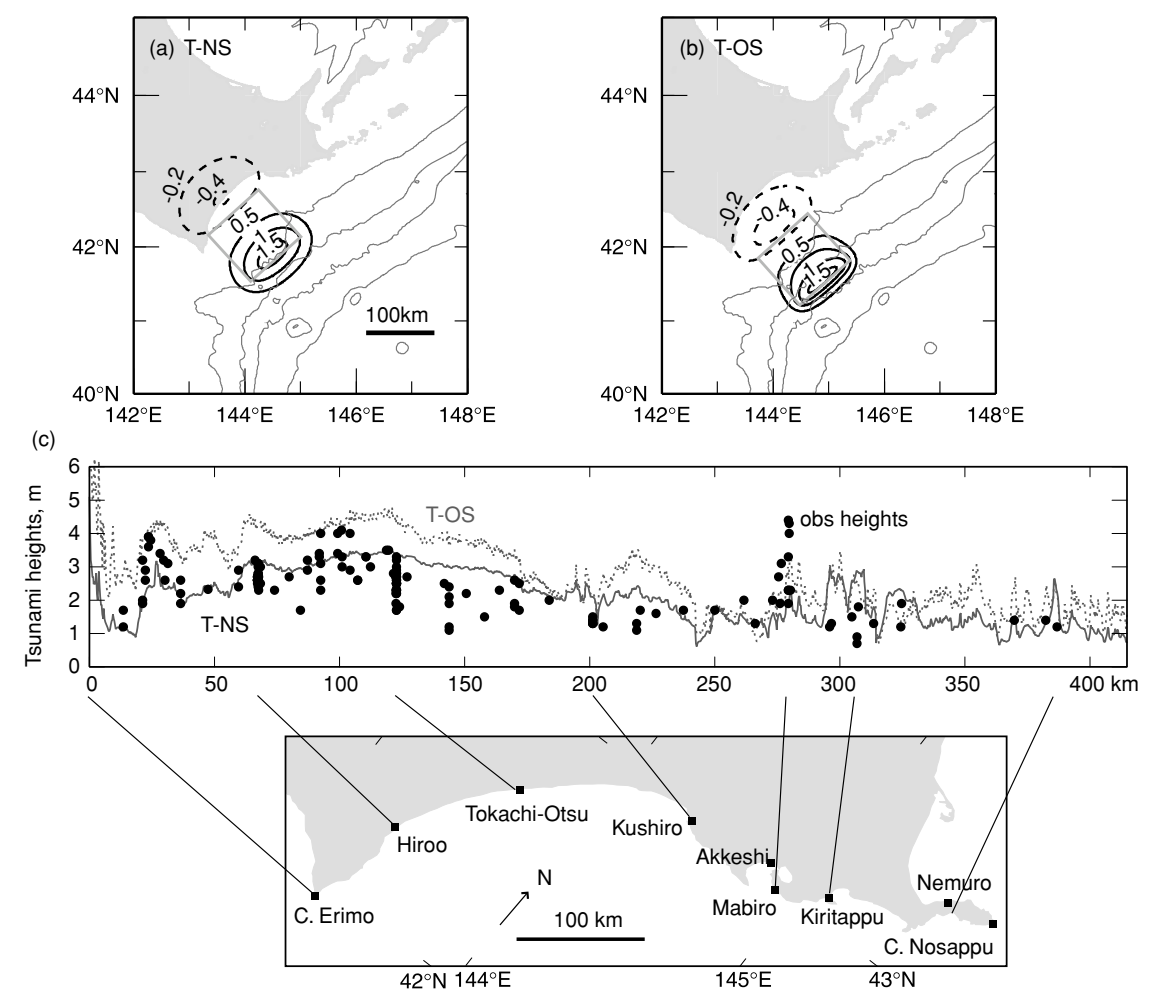

Fig. 8. The 2003 Tokachi-oki earthquake. Computed seafloor and ground deformation due to Near Shore model (a) and Off Shore model (b). (c) Coastal tsunami heights computed from the above models, compared with tsunami heights measured by several survey teams (Tanioka et al., 2004b).

was found as high as $17 \mathrm{~m}$ above sea level, but none of the models can reproduce this height.

Around Pashukuru pond, only the interplate (T10N5) model can reproduce the inundation distance more than $3.5 \mathrm{~km}$ from the coast, reaching the inland limit of the $17 \mathrm{th}$ century tsunami deposits. The TN5 and giant fault models produce tsunami inundation for about $2 \mathrm{~km}$, while the tsunami earthquake model reaches about $1 \mathrm{~km}$. Because the topography around Pashuku pond is flat, the runup heights are about $2 \mathrm{~m}$ or less for all the models except for T10N5.

Around Oikamanai pond, the computed inundation distance or runup heights from all the models do not reach the location of the 17 th century tsunami deposits. The interplate (T10N5) model yields the largest inundation distance and runup heights, closer to the tsunami deposits (as far as $4.5 \mathrm{~km}$ from the coast), while other model yields much smaller distances and heights.

\section{Tsunami Source Models}

\subsection{The 17th century tsunami source model}

The computed tsunami inundation from different fault models indicates that interplate earthquake models produce the larger coastal heights and longer inundation distances than those from the giant fault or tsunami earthquake model. For the 17 th century tsunami, interplate earthquake seems to be the best model for the tsunami source. The fault needs to be $300 \mathrm{~km}$ to cover both the Tokachi and Nemuro coasts, where the tsunami deposits were found. It represents the multi-segment rupture.

In order to reproduce the tsunami inundation on the Tokachi coast, large $(10 \mathrm{~m}) \mathrm{slip}$ is needed at least for the Tokachi segment. The T10N5 model has $10 \mathrm{~m}$ slip on a
$100 \mathrm{~km}$-long segment off the Tokachi coast and $5 \mathrm{~m}$ slip on a $200 \mathrm{~km}$-long segment off the Nemuro coast. Such a variable slip fault yields seismic moment of $8 \times 10^{21} \mathrm{~N} \mathrm{~m}$, or moment magnitude $M_{\mathrm{w}}$ of 8.5 , assuming the rigidity of $4 \times 10^{10} \mathrm{~N} / \mathrm{m}^{2}$ (Table 1).

The computed tsunami heights from the T10N5 model are too high along the Sanriku coast. As mentioned in Section 5.1, the tsunami heights computed from the T10N5 model are more than $4 \mathrm{~m}$, similar to the 1677 tsunami, at places in northern Sanriku. Because this and earlier (1611) tsunamis were documented in the historical records, if the tsunami source were the T10N5 model, the tsunami and damage must have been documented on the Sanriku coast. This leaves the T10N5 model imperfect for the 17th century tsunami source. While the absence of historical records is difficult to compare with a model, more heterogeneous fault model may be able to reduce the tsunami heights in Sanriku to resolve this problem.

\subsection{The older tsunami source model}

On the Tokachi coast, Ts3 deposits show larger inundation or higher altitude than the penultimate Ts4 deposits. On the contrary, on the Nemuro coast (Nambu and Kiritappu), inferred tsunami inundation and runup heights are larger for the older (Ts4) deposits. This suggests that the Ts4 tsunami in the 13-14th century had slip distribution different from the Ts 3 tsunami or the 17 th century earthquake. For the 17th century earthquake, larger slip on the Tokachi segment is needed to reproduce Ts 3 deposits. The 13-14th century tsunami seems to have a relatively larger slip on the Nemuro segment. Hence the slip distribution of recurring multi-segment fault earthquake may be different for each cycle. 


\subsection{The 2003 Tokachi-oki tsunami model}

How was the 17th century earthquake source different from the recent earthquakes, such as the 2003 Tokachi-oki earthquake? While the detailed slip distribution of the 2003 earthquake was studied by analysis of seismograms (Yamanaka and Kikuchi, 2003) or tsunami waveforms (Tanioka et al., 2004a), we model it by a simple rectangular fault of $100 \mathrm{~km} \times 100 \mathrm{~km}$ in order to compare the characteristics. Two different locations and depth ranges are tested (Table 1, Figs. 8(a), (b)). One is offshore location (T-OS model), with the depth range of 17 to $51 \mathrm{~km}$. This is the same location as the Tokachi segment of the TN5 or T10N5 model. The other fault model is located nearshore (T-NS model) in the deeper part of plate interface, at the depth range of 34 to $68 \mathrm{~km}$. The seismogram and tsunami analyses indicate that location of the 2003 source is closer to the T-NS model (Yamanaka and Kikuchi, 2003; Tanioka et al., 2004a). The average slip is assumed to be $5 \mathrm{~m}$ for both models, making the seismic moment of $2 \times 10^{21} \mathrm{~N} \mathrm{~m}$, or moment magnitude $M_{\mathrm{w}}$ of 8.1, similar the 2003 Tokachi-oki earthquake, assuming the rigidity of $4 \times 10^{10} \mathrm{~N} / \mathrm{m}^{2}$.

The coastal tsunami heights are computed from both models and compared with those of the 17th century tsunami models. The coastal heights of the TN5 model are up to $7 \mathrm{~m}$ along the Tokachi coast (Fig. 4), while those from the T-OS model are less than $5 \mathrm{~m}$ (Fig. 8). This shows that the longer fault produces the larger tsunami heights even if the slip amount is the same, and supports that the 17th century tsunami source was longer extending over multiple segments. Comparison of tsunami heights from the T-OS and T-NS models indicates that the offshore model (T-OS) produces large tsunami heights than the nearshore model (T-NS).

The measured runup heights of the 2003 Tokachi-oki earthquake (Tanioka et al., 2004b; Fig. 8(c)) are similar or smaller than the T-NS model, indicating that the nearshore (T-NS) model better reproduces the 2003 tsunamis than the offshore (T-OS) model, while the slip amount may be smaller than modeled here. It should be noted that the fault model inferred by Tanioka et al. (2004a) is based on the tsunami waveforms (mostly the initial parts only) recorded on tide and ocean-bottom tsunami gauges, while the comparison in this paper was made for the maximum tsunami heights on the coasts.

The above comparisons indicate that the multi-segment rupture and the offshore location, compared with the recent 2003 Tokachi-oki earthquake, are responsible for the unusually large tsunami in the 17 th century.

\section{Conclusions}

We computed tsunami generation and propagation from several fault models and compared the coastal heights and inundation areas with the inferred tsunami heights (Hirakawa et al., 2005) and the distribution of tsunami deposits (Nanayama et al., 2003, 2007) from the 17th century earthquake along the Kuril trench. The results for each fault model are summarizes as follows.

(1) The giant fault model (width: $250 \mathrm{~km}$, depth range: 0-85 km), which produces coseismic uplift of the Pa- cific coast, yields the lowest tsunami heights on the Hokkaido coast, and smaller inundation areas than the distribution of tsunami deposits. On the Sanriku coast, it yields the largest tsunami heights, because of the largest seismic moment.

(2) The tsunami earthquake model (width: $50 \mathrm{~km}$, depth range: $0-17 \mathrm{~km}$ ) yields locally variable coastal heights on the Hokkaido coast and the smallest heights on the Sanriku coast. This model, with the shortest wavelength in seafloor deformation, yields little tsunami inundation to coastal marshes where the 17 th century tsunami deposits were found.

(3) The interplate earthquake (TN5) model (width: $100 \mathrm{~km}$, depth range: $34-51 \mathrm{~km}$ ) produces the largest tsunami heights on the Hokkaido coast. On the Sanriku coast, the coastal tsunami heights are between the giant fault and tsunami earthquake models, as expected from the seismic moments. This model yields the largest tsunami inundation, comparable to the distribution of tsunami deposits along the Nemuro coast such as Kiritappu marsh.

(4) In the above, the fault length and the slip amount were fixed at $300 \mathrm{~km}$ and $5 \mathrm{~m}$, indicating a rupture on multiple (Tokachi and Nemuro) segments. In order to reproduce the distribution of tsunami deposits in marshes on the Tokachi coast (around Pahsukuru and Oikamanai ponds), the fault slip on the Tokachi segment needs to be as large as $10 \mathrm{~m}$. This variable slip model (T10N5), with seismic moment of $8 \times 10^{21} \mathrm{~N} \mathrm{~m}\left(M_{\mathrm{w}}\right.$ 8.5 ), roughly reproduces both coastal tsunami heights and distribution of tsunami deposits in the 17th century. However, the calculated coastal tsunami heights on the Sanriku coast are more than $3 \mathrm{~m}$, exceeding the estimated detection threshold based on historical documents.

(5) The recent 2003 Tokachi-oki earthquake can be modeled by a simple fault $(100 \mathrm{~km} \times 100 \mathrm{~km}, 5 \mathrm{~m}$ slip$)$ located at the deeper part of plate interface closer to the coast. The comparison indicates that the 17 th century tsunami source was longer over multi-segments and located offshore than the 2003 earthquake.

Acknowledgments. Professors Minoru Kasahara, Kazuomi Hirakawa, Yuichiro Tanioka and Yuichi Nishimura of Hokkaido University, members of the advisory committee for the tsunami inundation maps (Geological Survey of Japan, 2004) offered us valuable data and advice during the course of this study. Drs. Yushiro Fujii, Yuichi Namegaya, Yuki Sawai and two anonymous reviewers carefully reviewed the draft and provided numerous comments that improved the paper.

\section{References}

Aida, I., Reliability of a tsunami source model derived from fault parameters, J. Phys. Earth, 26, 57-73, 1978.

Atwater, B. F., R. Furukawa, E. Hemphill-Haley, Y. Ikeda, K. Kashima, K. Kawase, H. M. Kelsey, A. L. Moore, F. Nanayama, Y. Nishimura, S. Odagiri, Y. Ota, S.-C. Park, K. Satake, Y. Sawai, and K. Shimokawa, Seventeenth-century uplift in eastern Hokkaido, Japan, The Holocene, 14(4), 487-501, 2004.

Earthquake Research Committee, Long-term evaluation of seismicity along the Kuril Trench, Publications of Earthquake Research Committee, II, 1-74, 2004 (in Japanese). 
Geological Survey of Japan, Tsunami inundation maps for the Pacific coast of Hokkaido, Digital Geological Map series, EQ-1 (CD-ROM), 2004 (in Japanese).

Hamada, N. and Y. Suzuki, Re-examination of aftershocks of the 1952 Tokachi-oki earthquake and a comparison with those of the 2003 Tokachi-oki earthquake, Earth Planets Space, 56, 341-345, 2004.

Hatori, T., Source area of the tsunami off the Nemuro Peninsula in 1973 and its comparison with the tsunami in 1894, Special Bull. Earthq. Res. Inst. Univ. Tokyo, 13, 67-76, 1974 (in Japanese with English abstract).

Hatori, T., Tsunami magnitude and wave source regions of historical Sanriku tsunamis in northeast Japan, Bull. Earthq. Res. Inst. Univ. Tokyo, 50, 397-414, 1975 (in Japanese with English abstract).

Hatori, T., Source area of the east Hokkaido tsunami generated in April, 1843, Bull. Earthq. Res. Inst. Univ. Tokyo, 59, 423-431, 1984 (in Japanese with English abstract).

Hirakawa, K., Y. Nakamura, and Y. Nishimura, Mega-tsunamis since last 6500 years along the Pacific coast of Hokkaido, Chikyu Monthly, Special Issue No. 49, 173-180, 2005 (in Japanese).

Hirata, K., E. Geist, K. Satake, Y. Tanioka, and S. Yamaki, Slip distribution of the 1952 Tokachi-oki earthquake $(M$ 8.1) along the Kuril trench deduced from tsunami waveform inversion, J. Geophys. Res., 108, 2196, doi:10.1029/2002JB001976, 2003.

Hirata, K., Y. Tanioka, K. Satake, S. Yamaki, and E. L. Geist, The tsunami source area of the 2003 Tokachi-oki earthquake estimated from tsunami travel times and its relationship to the 1952 Tokachi-oki earthquake, Earth Planets Space, 56, 367-372, 2004.

Hyndman, R. D., M. Yamano, and D. A. Oleskevich, The seismogenic zone of subduction thrust faults, Island Arc, 6, 244-260, 1997.

Ikeda, Y., Implication of active fault study for the present-day tectonics of the Japan arc, Active Fault Res., 15, 93-99, 1996 (in Japanese).

Imamura, A., Past tsunamis of the Sanriku coast, Japanese J. Astron. Geophys., 11, 79-93, 1934.

Iwasaki, T. and A. Mano, Two-dimensional numerical simulation of tsunami run-ups in the Eulerian description, Proc. 26th conf. Coastal Engineering, JSCE, 70-72, 1979 (in Japanese).

Ito, T., S. Yoshioka, and S. Miyazaki, Interplate coupling in northeast Japan deduced from inversion analysis of GPS data, Earth Planet. Sci. Lett., 176, 117-130, 2000.

IUGG/IOC Time Project, Numerical method of tsunami simulation with the leap-frog scheme, IOC Manuals and Guides, No. 35, 126 pp., UNESCO, 1997.

Kanamori, H., Mechanism of tsunami earthquakes, Phys. Earth Planet. Inter., 6, 246-259, 1972.

Kelsey, H. M., K. Satake, Y. Sawai, B. Sherrod, K. Shimokawa, and M. Shishikura, Recurrence of postseismic coastal uplift, Kuril subduction zone, Japan, Geophys. Res. Lett., 33, L3315, doi:10.1029/ 2006GL026052, 2006.

Mansinha, L. and D. E. Smylie, The displacement fields of inclined faults, Bull. Seismol. Soc. Am., 61, 1433-1440, 1971.

Nanayama, F., K. Satake, R. Furukawa, K. Shimokawa, B. F. Atwater, K. Shigeno, and S. Yamaki, Unusually large earthquakes inferred from tsunami deposits along the Kuril trench, Nature, 424, 660-663, 2003.

Nanayama, F., R. Furukawa, K. Shigeno, A. Makino, Y. Soeda, and Y. Igarashi, Nine unusually large tsunami deposits from the past 2000 years at Kiritappu marsh along the southern Kuril Trench, Sediment. Geol., 200, 275-294, 2007.

Okamura, Y., T. Tsujino, K. Arai, T. Sasaki, K. Satake, and M. Joshima, Fore arc structure and plate boundary earthquake sources along the southwestern Kuril subduction zone, J. Geophys. Res., 113, B06305,
doi:10.1029/2007JB005246, 2008.

Satake, K., Detection of Kuril subduction-zone earthquakes from remote historic records in Honshu, Japan, between 1656 and 1867, Ann. Geophys., 27, 369-378, 2004.

Satake, K., F. Nanayama, S. Yamaki, Y. Tanioka, and K. Hirata, Variability among tsunami sources in the 17 th-21st centuries along the southern Kuril trench, in Tsunamis: Case Studies and Recent Developments, edited by K. Satake, 157-170, Springer, 2005.

Satake, K., K. Hirata, S. Yamaki, and Y. Tanioka, Re-estimation of tsunami source of the 1952 Tokachi-oki earthquake, Earth Planets Space, 58, 535-542, 2006.

Sawai, Y., Evidence for the 17th-century tsunamis generated on the KurilKamchatka subduction zone, Lake Tokotan, Hokkaido, Japan, J. Asian Earth Sci., 20, 903-911, 2002.

Sawai, Y., K. Satake, T. Kamataki, H. Nasu, M. Shishikura, B. F. Atwater, B. P. Horton, H. M. Kelsey, T. Nagumo, and M. Yamaguchi, Transient uplift after a 17th-century earthquake along the Kuril subduction zone, Science, 306, 1918-1920, 2004.

Shimamoto, T., T. Seno, and S. Uyeda, A simple rheological framework for comparative subductology, AGU Geophys. Monograph, 76 (IUGG volume 16), 39-52, 1993.

Shimazaki, K., Nemuro-oki earthquake of June 17, 1973; A lithospheric rebound at the upper half of the interface, Phys. Earth Planet. Inter., 9, 315-327, 1974.

Smith, W. H. F. and D. T. Sandwell, Global sea floor topography from satellite altimetry and ship depth soundings, Science, 277, 1956-1962, 1997.

Suwa, Y., S. Miura, A. Hasegawa, T. Sato, and K. Tachibana, Interplate coupling beneath NE Japan inferred from three-dimensional displacement field, J. Geophys. Res., 111, B04402, doi:10.1029/2004JB003203, 2006.

Tanioka, Y. and K. Satake, Fault parameters of the 1896 Sanriku tsunami earthquake estimated from tsunami numerical modeling, Geophys. Res. Lett., 23, 1549-1552, 1996.

Tanioka, Y., K. Hirata, R. Hino, and T. Kanazawa, Slip distribution of the 2003 Tokachi-oki earthquake estimated from tsunami waveform inversion, Earth Planets Space, 56, 373-376, 2004a.

Tanioka, Y., Y. Nishimura, K. Hirakawa, F. Imamura, I. Abe, Y. Abe, K. Shindou, H. Matsutomi, T. Takahashi, K. Imai, K. Harada, Y. Namegaya, Y. Hasegawa, Y. Hayashi, F. Nanayama, T. Kamataki, Y. Kawata, Y. Fukasawa, S. Koshimura, Y. Hada, Y. Azumai, K. Hirata, A. Kamikawa, A. Yoshikawa, T. Shiga, M. Kobayashi, and S. Masaka, Tsunami run-up heights of the 2003 Tokachi-oki earthquake, Earth Planets Space, 56, 359-365, 2004b.

Tanioka, Y., K. Satake, and K. Hirata, Recurrence of recent large earthquakes along the southernmost Kuril-Kamchatka subduction zone, $A G U$ Geophys. Monograph, 172, 145-152, 2007.

Tichelaar, B. W. and L. J. Ruff, Depth of seismic coupling along subduction zone, J. Geophys. Res., 98, 2017-2037, 1993.

Utsu, T., Seismicity Studies: A Comprehensive Review, 876 pp., University of Tokyo Press, 1999 (in Japanese).

Yamanaka, Y. and M. Kikuchi, Source processes of the Tokachi-oki earthquake on September 26, 2003 inferred from teleseismic body waves, Earth Planets Space, 55, e21-e24, 2003.

K. Satake (e-mail: satake@eri.u-tokyo.ac.jp), F. Nanayama, and S. Yamaki 